\title{
Numerical Simulation of Underwater Runoff Propagation in the Heraklean Peninsula Coastal Zone
}

\author{
V.A. Ivanov, V.V. Fomin \\ Marine Hydrophysical Institute, Russian Academy of Sciences, Sevastopol, Russian Federation \\ e-mail: vaivanov@inbox.ru, fomin.dntmm@gmail.com
}

\begin{abstract}
The problem of waste water propagation from the underwater source over the Heraklean Peninsula coastal zone is studied based on the three-dimensional numerical model simulating a break on the Sevastopol major municipal sewage trunk line. The calculations are made for three types of density stratification obtained by R/V Biryuza in September, 2015 and May, 2016. The outlet depth varied from 15 to $30 \mathrm{~m}$. Numerical simulation was carried out on a uniform rectangular grid with $20 \mathrm{~m}$ horizontal step and $1 \mathrm{~m}$ vertical discreteness. Time integration step was $5 \mathrm{~s}$, total integration time was $12 \mathrm{~h}$. The effect of positive buoyancy in the model was created by fresh water inflow. It is revealed that the wastewater rising to the surface depends on the features of density stratification. The main factor preventing the polluted water from rising is the presence of the density drop layers above the outlet. The general trend consisting in increase of the polluted layer area accompanied by weakening of density stratification and decrease of current velocities is observed. It is found that the wastewater field close to the outlet consists of a stem and a jet oriented along the direction of the ambient current. As the current velocity increases, the top of the stem lowers and the jet sinks, its transverse size simultaneously decreases
\end{abstract}

Keywords: coastal zone of the Crimea, wastewater, underwater outlet, density stratification, numerical simulation.

DOI: 10.22449/1573-160X-2016-6-82-95

(C) 2016, V.A. Ivanov, V.V. Fomin

(C) 2016, Physical Oceanography

Introduction. One of the main sources of coastal water pollution is underwater runoffs from submerged sewers. To study the formation and propagation of discharged water field, the contact and remote observation methods [1 -6], as well as physical and mathematical modeling, [1, $7-10]$ were applied.

Underwater outlets due to fresher water run into the sea provide a local positive buoyancy source at the bottom. It forms a stable system of turbulent currents in the form of stems and underwater jets. These current systems are commonly called plumes. Turbulent diffusion and advective transport cause the processes of the polluted water dilution in the plume. The dilution intensity (fold) is under the influence of the following factors: outlet type (point or distributed source in the form of a diffuser), water discharge in the source, dynamic conditions of the receiving environment, sea and wastewater density difference, etc. Rising from the outlet, the wastewaters may be delayed by density stratification on the neutral buoyancy horizon, which usually corresponds to the lower part of pycnocline, and propagate further under the pycnocline in the horizontal direction.

The current level of anthropogenic load on the coastal zone of Crimea is very significant [11]. Therefore, the study of the features of wastewater field formation and propagation off the Crimean coast is an important and relevant task.

The main diffuser of underwater wastewater outlet of Sevastopol is in the area of the Heraclean Peninsula Blue Bay $3 \mathrm{~km}$ away from the coast at $90 \mathrm{~m}$ depth. 
Integrated field studies by R/V Biryuza in September, 2015 and May, 2016 revealed no traces of contamination just off the diffuser. At the same time a source of contamination was found above the sewage trunk line near the coast. It contains the chemical components typical of sewage waters, which form turbid layers at depths of $10-25$ meters in this area. This source of pollution is likely the consequence of a break on the major municipal sewage trunk line. In this regard, it is of interest to find out the depth of the source location and types of density stratification under which the wastewater can rise into the surface sea layers.

The present article is aimed at mathematical modeling of the wastewater propagation over the Heraklean Peninsula coastal zone from the underwater source simulating a break on the Sevastopol major municipal sewage trunk line. Among the objectives of the work is a study of the features of the wastewater field spatial structure in the area of underwater outlet for the various types of density stratification and different velocity values of ambient currents, as well as determination of the conditions under which the wastewaters can rise to the sea surface.

Problem statement and governing equations. Introduce the Cartesian coordinate system $(x, y, z), z$ axis is directed vertically. Consider a rectangular basin with a constant depth $h_{0}$. It is filled with continuously stratified fluid and limited by the liquid side boundaries.

At the initial time the three-dimensional thermohydrodynamic fields and the contaminant concentration field are described by the following conditions:

$$
u=U_{0}, u=w=0, \eta=0, T=T_{0}(z), S=S_{0}(z), C=0 .
$$

Here $u, v$ and $w$ are the current velocity components along $x, y$ and $z$ axes correspondingly; $U_{0}$ is the constant ambient velocity directed along $x$ axis; $\eta$ is the basin free surface coordinate; $T$ and $S$ are the water temperature and salinity; $T_{0}(z)$ is the ambient temperature distribution; $S_{0}(z)$ is the ambient salinity distribution; $C$ is the contaminant concentration. To simplify the problem the impurity is assumed to be conservative.

At the time moment $t>0$ at the point with coordinates $\left(x_{\mathrm{p}}, y_{\mathrm{p}}, z_{\mathrm{p}}=-h_{0}\right)$ at the bottom of the basin the local source simulating the wastewater discharge starts to act. The following parameters of the source are known: $Q_{p}$ is the water discharge; $d$ is the horizontal size; $w_{\mathrm{p}}=Q_{\mathrm{p}} / d^{2}$ is the water inflow velocity; $T_{\mathrm{p}}, S_{\mathrm{p}}-$ inflow water temperature and salinity; $C_{\mathrm{p}}$ is the impurity concentration at the source exit.

The aim is to study the evolution of the field of admixture caused by the action of a source for various types of $T_{0}(z)$ and $S_{0}(z)$ and different values of $h_{0}$ and $U_{0}$. To solve the problem, we use a numerical model of baroclinic water circulation $[12,13]$. The model is based on three-dimensional $\sigma$-coordinate equations of ocean dynamics in the Boussinesq approximation and hydrostatic equations of the following form (toting over repeated indices $\alpha$ and $\beta$ from 1 to 2 is assumed):

$$
\begin{aligned}
& \quad \frac{\partial}{\partial t}\left(D u_{\alpha}\right)+\Lambda u_{\alpha}+\varepsilon_{\alpha \beta} f D u_{\beta}+g D \frac{\partial \eta}{\partial x_{\alpha}}+D B_{\alpha}= \\
& =\frac{\partial}{\partial x_{\beta}}\left(D \tau_{\alpha \beta}\right)+\frac{\partial}{\partial \sigma}\left(\frac{K_{M}}{D} \frac{\partial u_{\alpha}}{\partial \sigma}\right),
\end{aligned}
$$

PHYSICAL OCEANOGRAPHY NO. 6 (2016) 


$$
\begin{gathered}
\frac{\partial \eta}{\partial t}+\frac{\partial}{\partial x_{\alpha}}\left(D u_{\alpha}\right)+\frac{\partial w_{*}}{\partial \sigma}=0, \\
\frac{\partial}{\partial t}(D T)+\Lambda T=\frac{\partial}{\partial x_{\beta}}\left(A_{T} \frac{\partial T}{\partial x_{\beta}}\right)+\frac{\partial}{\partial \sigma}\left(\frac{K_{T}}{D} \frac{\partial T}{\partial \sigma}\right), \\
\frac{\partial}{\partial t}(D S)+\Lambda S=\frac{\partial}{\partial x_{\beta}}\left(A_{S} \frac{\partial S}{\partial x_{\beta}}\right)+\frac{\partial}{\partial \sigma}\left(\frac{K_{S}}{D} \frac{\partial S}{\partial \sigma}\right), \\
\frac{\partial}{\partial t}(D C)+\Lambda C=\frac{\partial}{\partial x_{\beta}}\left(A_{C} \frac{\partial C}{\partial x_{\beta}}\right)+\frac{\partial}{\partial \sigma}\left(\frac{K_{C}}{D} \frac{\partial C}{\partial \sigma}\right), \\
\Lambda \varphi=\frac{\partial}{\partial x_{\beta}}\left(D u_{\beta} \varphi\right)+\frac{\partial}{\partial \sigma}\left(w_{*} \varphi\right), \quad B_{\alpha}=\frac{g}{\rho_{0}}\left(\frac{\partial}{\partial x_{\alpha}} D \int_{\sigma}^{0} \rho d \sigma^{\prime}+\sigma \frac{\partial D}{\partial x_{\alpha}} \rho\right), \\
\tau_{\alpha \alpha}=2 A_{M} \frac{\partial u_{\alpha}}{\partial x_{\alpha}}, \tau_{\alpha \beta}=\tau_{\beta \alpha}=A_{M}\left(\frac{\partial u_{\beta}}{\partial x_{\alpha}}+\frac{\partial u_{\alpha}}{\partial x_{\beta}}\right),
\end{gathered}
$$

where $\left(x_{1}, x_{2}\right)=(x, y) ; \sigma$ is the dimensionless vertical coordinate varying within 1 to $0 ; D=h_{0}+\eta$ is the dynamic depth; $\tau_{\alpha \beta}$ are the turbulent stress tensor components; $A_{M}, K_{M}, A_{T}, K_{T}, A_{S}, K_{S}, A_{C}, K_{C}$ are the coefficients of turbulent viscosity and diffusion; $g$ is the free fall acceleration; $f$ is the Coriolis parameter; $\rho_{0}$ is the mean water density; $\varepsilon_{\alpha \beta}=0$ where $\alpha=\beta ; \varepsilon_{12}=-1 ; \varepsilon_{21}=1$.

The unknown variables of the system (2) - (9) are: $\left(u_{1}, u_{2}\right)=(u, v)$ - horizontal components of the velocity; $w_{*}$ is the current velocity component normal to the surfaces $\sigma=$ const; $\rho$ is the seawater density.

On the free surface ( $\sigma=0$ ) the boundary conditions are as follows:

$$
w_{*}=0, \frac{K_{M}}{D} \frac{\partial u_{\alpha}}{\partial \sigma}=0, \frac{K_{T}}{D} \frac{\partial T}{\partial \sigma}=0, \frac{K_{S}}{D} \frac{\partial S}{\partial \sigma}=0, \frac{K_{C}}{D} \frac{\partial C}{\partial \sigma}=0 .
$$

The boundary conditions at the bottom outside the source ( $\sigma=-1, x \neq x_{\mathrm{p}}$, $\left.y \neq y_{\mathrm{p}}\right)$ are:

$$
w_{*}=0, \frac{K_{M}}{D} \frac{\partial u_{\alpha}}{\partial \sigma}=\mu|u| u_{\alpha}, \frac{K_{T}}{D} \frac{\partial T}{\partial \sigma}=0, \frac{K_{S}}{D} \frac{\partial S}{\partial \sigma}=0, \frac{K_{C}}{D} \frac{\partial C}{\partial \sigma}=0,
$$

where $\mu$ is the bottom friction coefficient; $|u|=\sqrt{u_{1}^{2}+u_{2}^{2}}$.

The boundary conditions at the bottom in the source $\left(\sigma=-1, x=x_{\mathrm{p}}, y=y_{\mathrm{p}}\right)$ can be written as [14]:

$$
w_{*}=w_{\mathrm{p}}, \frac{K_{M}}{D} \frac{\partial u_{\alpha}}{\partial \sigma}=\mu|u| u_{\alpha},
$$




$$
w_{\mathrm{p}} T-\frac{K_{T}}{D} \frac{\partial T}{\partial \sigma}=w_{\mathrm{p}} T_{\mathrm{p}}, \quad w_{\mathrm{p}} S-\frac{K_{S}}{D} \frac{\partial S}{\partial \sigma}=w_{\mathrm{p}} S_{\mathrm{p}}, \quad w_{\mathrm{p}} C-\frac{K_{C}}{D} \frac{\partial C}{\partial \sigma}=w_{\mathrm{p}} C_{\mathrm{p}} .
$$

The coefficients of horizontal turbulent viscosity and diffusion are calculated using the Smagorinsky model [15]. To determine the coefficients of vertical turbulent viscosity and diffusion, Mellor - Yamada model is applied [12, 16].

Numerical algorithm for solving the system (2) - (13) is based on the splitting of tasks in the barotropic and baroclinic modes and the use of explicit schemes for horizontal coordinates and implicit schemes for the $\sigma$-coordinate. To approximate the advective operators $\Lambda$ in (2), (4) - (6) TVD schemes are applied [17, 18]. These schemes are monotonic, which is a required condition for adequate modeling of the fields with high spatial gradients. Detailed description of the numerical model algorithm is given in [12].

Numerical experiments and results discussion. Numerical experiments were conducted for a square pool of $2 \mathrm{~km}$ and a depth of $\mathrm{h}_{0}$. The source coordinates were $\left(x_{\mathrm{p}}, y_{\mathrm{p}}, z_{\mathrm{p}}\right)=\left(600 \mathrm{~m}, 1000 \mathrm{~m},-h_{0}\right)$ and its horizontal dimension was $d=20 \mathrm{~m}$. The nominal water discharge at the source was $Q_{\mathrm{p}}=1.4 \mathrm{~m}^{3} / \mathrm{s}$ and the impurity concentration therein was $C_{\mathrm{p}}=500 \mathrm{mg} / \mathrm{l}$. We assumed that the inflowing water had zero salinity $\left(S_{p}=0\right)$, and its temperature was equal to that of the environment, i. e. $T_{\mathrm{p}}=T_{0}\left(-h_{0}\right)$. Thus, the positive buoyancy effect was created in the underwater source due to fresh water inflow.

For the problem under consideration, the Froude number has the form $\mathrm{Fr}=w_{\mathrm{p}} / \sqrt{g^{\prime} d}$, where $g^{\prime}=g\left(\rho_{\mathrm{b}}-\rho_{\mathrm{p}}\right) / \rho_{\mathrm{b}}, \rho_{\mathrm{p}}$ is water density in the source, $\rho_{\mathrm{b}}$ is water density around the source. Under the accepted values of $Q_{\mathrm{p}}$ and $d$ the magnitude Fr is about 0.01 . This means that in the given statement of the problem the effect of buoyancy is predominant.

Numerical simulation was carried out on a uniform rectangular grid with a horizontal step $d$ and $1 \mathrm{~m}$ vertical discreteness. Time integration step was $5 \mathrm{~s}$, total integration time was $12 \mathrm{~h}$. During the first hour of model time the water discharge in the source was linearly increased within $0-1.4 \mathrm{~m}^{3} / \mathrm{s}$ and further remained unchanged. The boundary conditions at $\mathrm{x}=0$ are given as (1). On the other liquid boundaries the zero-gradient conditions $[12,14]$ were used, which is acceptable in the calculations for short periods of time.

The bottom friction coefficient in the boundary conditions (11) and (12) was defined by the formula $\mu=0,16 / \ln ^{2}\left(\delta z / z_{\mathrm{b}}\right)$ where $\delta z$ is the vertical distance from the bottom up to the point where the friction coefficient is determined; $z_{b}=0.01 \mathrm{~m}$ is the bottom surface roughness parameter. Calculations were carried out with zero Coriolis parameter. Equation of the seawater state (7) was defined by the UNESCO formula.

Density stratification on September, $9-10,2015$. In the first cycle of numerical experiments the profiles shown in Fig. $1 a, b$ were used as $T_{0}(z)$ and $S_{0}(z)$. Solid black curves correspond to the hydrological situation in September 9, 2015 (hereinafter - the first type of stratification); dashed black curves correspond to the hydrological situation in September 10, 2015 (hereinafter - the second type of stratification). These profiles are obtained by averaging over the ensemble of the 
stations that have been most closely located to the underwater runoff pipeline. As one can see, the profiles are markedly different from each other only in the upper 30 m layer. Analysis of the Brunt-Väisälä frequency profiles $N$ indicates that the highest water density gradients for both types of stratification are located in a layer of $15-30 \mathrm{~m}$ (Fig. 1, $c$ ). The mean value of $N$ in $0-30 \mathrm{~m}$ layer for each type of profiles is equal to 18.3 and 13.1 cycles/hour, respectively.

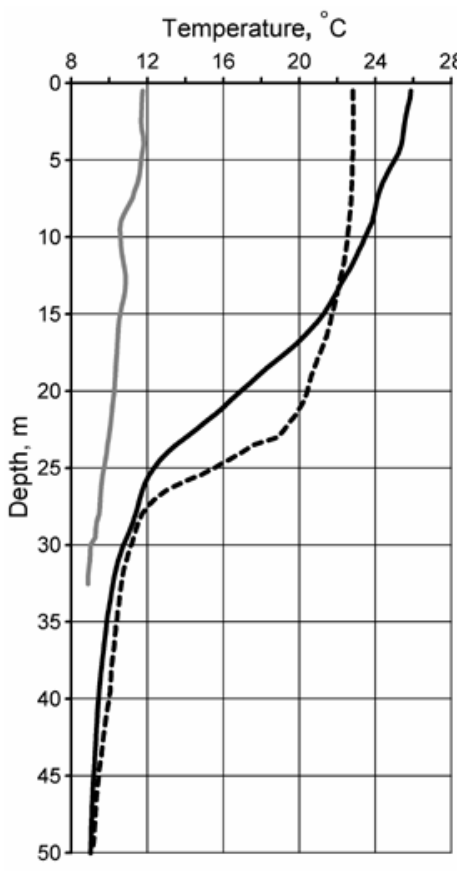

a

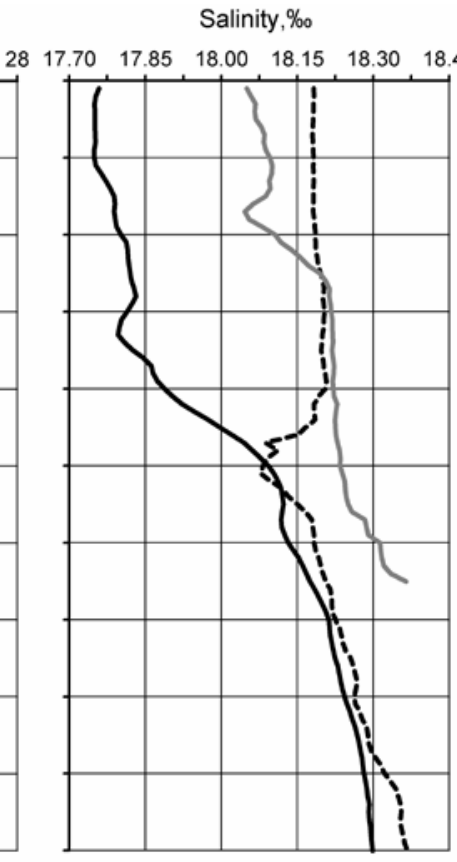

b

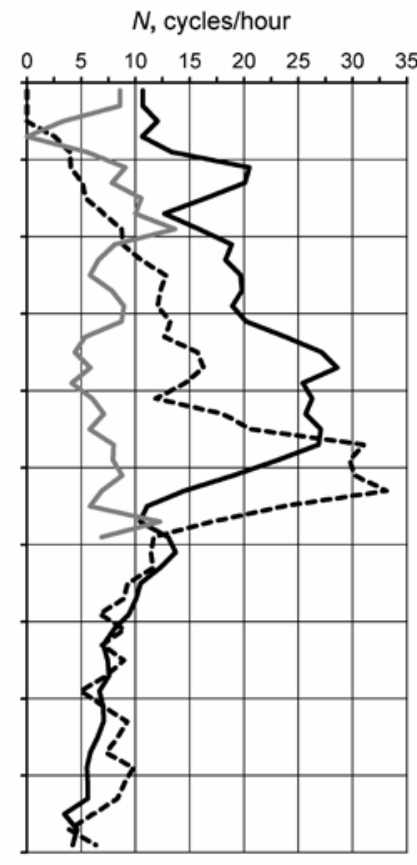

C

Fig. 1. Water temperature, salinity and Brunt-Väisälä frequency profiles in the area of the underwater outlet for three hydrological stations: solid black curves - Sept. 9, 2015; dotted black curves - Sept. 10, 2015; solid grey curves May, 20, 2016

The list of numerical experiments for the first and second types of stratification with different values $U_{0}$ and $h_{0}$ is given in Tab. 1. Selection of $U_{0}$ values is based on the results of $A D C P$-measurements in the Heraclean Peninsula area in the autumn of 2015 [19]. According to this data the mean current velocities were $\sim 0.05 \mathrm{~m} / \mathrm{s}$ during the observation period.

The main object of the research was the field of the $c$ impurity concentration, normalized by the amount of the impurity concentration in the source $C$ :

$$
c(x, y, z, t)=100 \% C(x, y, z, t) / C\left(x_{\mathrm{p}}, y_{\mathrm{p}},-h_{0}, t\right) .
$$

To identify areas of contamination (plume boundaries) a threshold value $c=$ $=5 \%$ was applied. The total area of contamination in each estimated layer with the thickness of $z_{k+1}-z_{k}$ was estimated by the following formula:

$$
V\left(z_{k+1 / 2}, t\right)=\sum_{i, j} \gamma\left(x_{i}, y_{j}, z_{k+1 / 2}, t\right),
$$




$$
\gamma\left(x_{i}, y_{j}, z_{k+1 / 2}, t\right)= \begin{cases}b, & c\left(x_{i}, y_{j}, z_{k+1 / 2}, t\right) \geq 5 \% \\ 0, & c\left(x_{i}, y_{j}, z_{k+1 / 2}, t\right)<5 \%\end{cases}
$$

where $k$ is the horizon number; $z_{k+1 / 2}=\left(z_{k+1}+z_{k}\right) / 2$ is the vertical coordinate of cell center; $x_{i}, y_{j}$ are horizontal coordinates of the difference grid; $b=d^{2}$ is the area of the horizontal section of the cell. From (15) it is clear that $V\left(z_{k+1 / 2}, t\right) / b$ is the total amount of cells in estimated layer $z_{k+1}-z_{k}$, for which $c \geq 5 \%$.

Table 1

\section{Maximum Areas of Contaminated Zones $(\max V)$ and Their Depth $\left(z_{\max }\right)$ for the First and Second Type of Stratification (TS) under Various Values of $U_{0}$ and $h_{0}$}

\begin{tabular}{cccccc|c|c|c|cc}
\hline$h_{0}, \mathrm{~m}$ & $U_{0}, \mathrm{~m} / \mathrm{s}$ & $\mathrm{TS}$ & $\begin{array}{c}\max V, \\
\mathrm{~km}^{2}\end{array}$ & $z_{\max }, \mathrm{m}$ & $h_{0}, \mathrm{~m}$ & $U_{0}, \mathrm{~m} / \mathrm{s}$ & $\mathrm{TS}$ & $\begin{array}{c}\max V, \\
\mathrm{~km}^{2}\end{array}$ & $z_{\max }, \mathrm{m}$ \\
\hline 15 & 0.025 & 1 & 0.52 & 5.5 & 15 & 0.025 & 2 & 3.54 & 0.5 \\
15 & 0.050 & 1 & 0.28 & 9.5 & 15 & 0.050 & 2 & 2.69 & 0.5 \\
15 & 0.075 & 1 & 0.37 & 14.5 & 15 & 0.075 & 2 & 0.05 & 0.5 \\
20 & 0.025 & 1 & 0.47 & 11.5 & 20 & 0.025 & 2 & 2.25 & 0.5 \\
20 & 0.050 & 1 & 0.31 & 13.5 & 20 & 0.050 & 2 & 0.85 & 0.5 \\
20 & 0.075 & 1 & 0.25 & 18.5 & 20 & 0.075 & 2 & 0.01 & 1.5 \\
25 & 0.025 & 1 & 0.40 & 18.5 & 25 & 0.025 & 2 & 0.35 & 13.5 \\
25 & 0.050 & 1 & 0.29 & 19.5 & 25 & 0.050 & 2 & 0.21 & 16.5 \\
25 & 0.075 & 1 & 0,42 & 19.5 & 25 & 0.075 & 2 & 0.26 & 21.5 \\
30 & 0.025 & 1 & 0.37 & 20.5 & 30 & 0.025 & 2 & 0.33 & 23.5 \\
30 & 0.050 & 1 & 0.28 & 22.5 & 30 & 0.050 & 2 & 0.29 & 24.5 \\
30 & 0.075 & 1 & 0.37 & 22.5 & 30 & 0.075 & 2 & 0.37 & 22.5 \\
\hline
\end{tabular}

The curves in Fig. 2 - 6 provide some insight into vertical distribution of the contaminated zones with different combinations of parameters $h_{0}$ and $U_{0}$.

Fig. 2 shows the $V / b$ distribution of the source at depth $h_{0}=15 \mathrm{~m}$ for the first and second types of stratification and three values of $U_{0}$. The curves correspond to the time point $t=12 \mathrm{~h}$. Under the first type of stratification the major contaminated zones are at a depth of $5 \mathrm{~m}$ and more (Fig. 2,a). It is due to the presence of the local density jump in the layer of $5-7 \mathrm{~m}$ (Fig. 1, c). Position of contaminated zones and their areas is largely affected by the velocity of ambient currents. Thus, 
with increasing of $U_{0}$ from 0.025 to $0.075 \mathrm{~m} / \mathrm{s}$ the zones become lower by $5 \mathrm{~m}$ to the bottom simultaneously decreasing their areas by $1.5-2$ times.
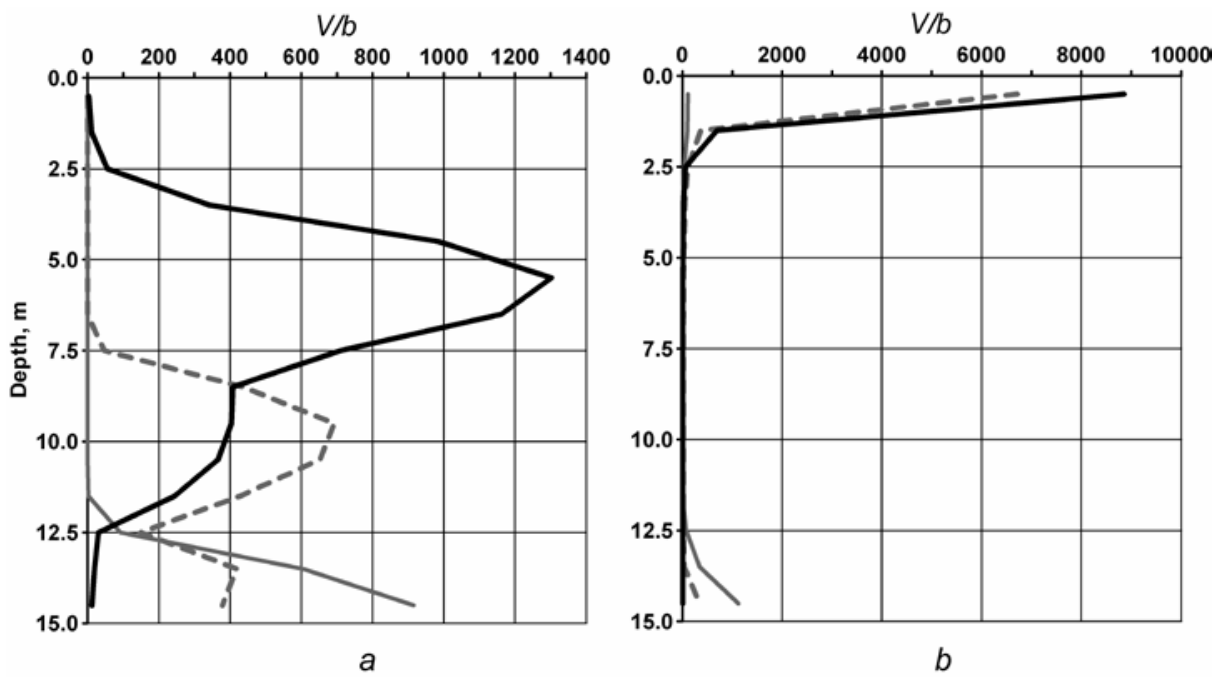

Fig. 2. Distribution of the contaminated zone in the vertical direction where $h_{0}=15 \mathrm{~m}$ for the first $(a)$ and second $(b)$ types of stratification where $t=12 \mathrm{~h}$. Solid black curves $-V / b$ where $U_{0}=$ $=0.025 \mathrm{~m} / \mathrm{s}$; dashed gray curves $-V / b$ where $U_{0}=0.050 \mathrm{~m} / \mathrm{s}$; solid gray curves $-V / b$ where $U_{0}=$ $=0.075 \mathrm{~m} / \mathrm{s}$

The vertical structure of contaminated zones for the second type of stratification (Fig. 2, b) differs from the case discussed above. Due to weak stratification in $0-20 \mathrm{~m}$ layer (Fig. $1, c$ ), polluted waters reach the basin surface and spread all over it in a $1-2 \mathrm{~m}$ thickness layer. When $U_{0}=0,075 \mathrm{~m} / \mathrm{s}$ the contamination area of the basin surface is two orders less than when $U_{0}=$ $=0.025 \mathrm{~m} / \mathrm{s}$ and $U_{0}=0.05 \mathrm{~m} / \mathrm{s}$.
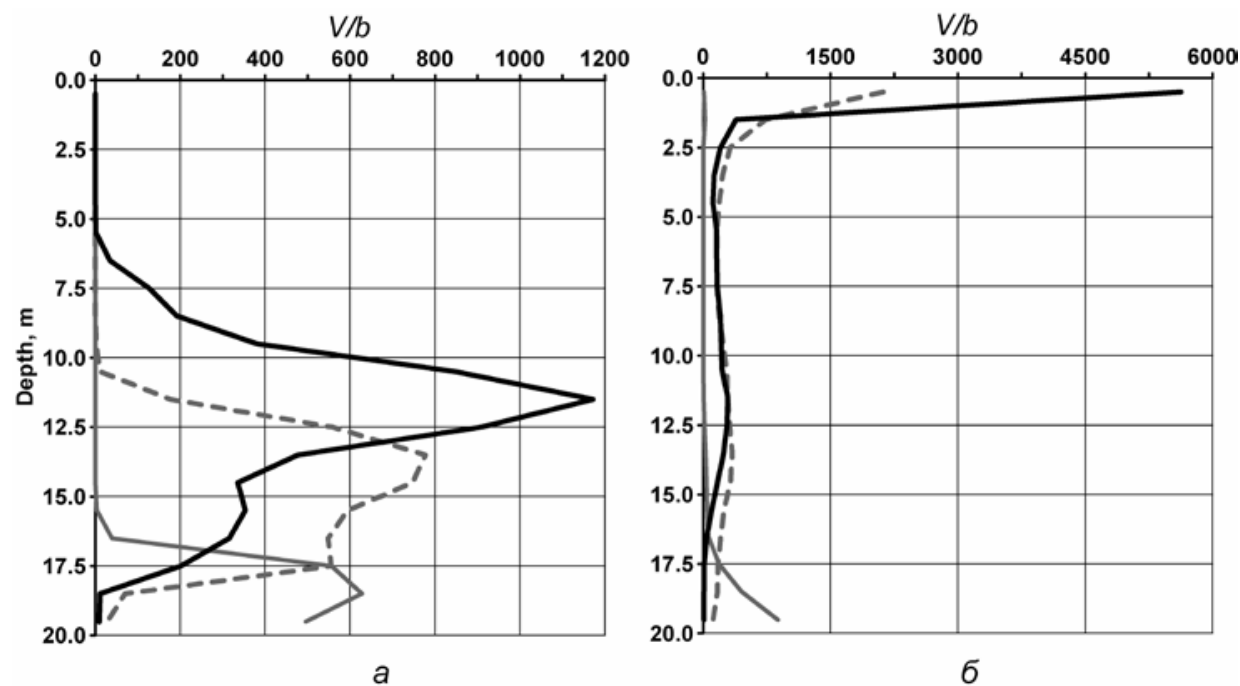

Fig. 3. Distribution of the contaminated zone in the vertical direction where $h_{0}=20 \mathrm{~m}$ for the first $(a)$ and second $(b)$ types of stratification where $t=12 \mathrm{~h}$. Colors and type of curves have the same match as in Fig. 2 
Fig. 4 shows the distribution of $V / b$ for $h_{0}=25 \mathrm{~m}$. In the first type of stratification under all values of $U_{0}$ the zones of contaminated waters are concentrated in the layer of $\sim 15-22 \mathrm{~m}$ (Fig. 4, a). In the second type of stratification, the position of these zones depends on velocity of the ambient currents. Thus, the increase of $U_{0}$ from 0.025 to $0.075 \mathrm{~m} / \mathrm{s}$ deepens the zones from 13 to $22 \mathrm{~m}$.
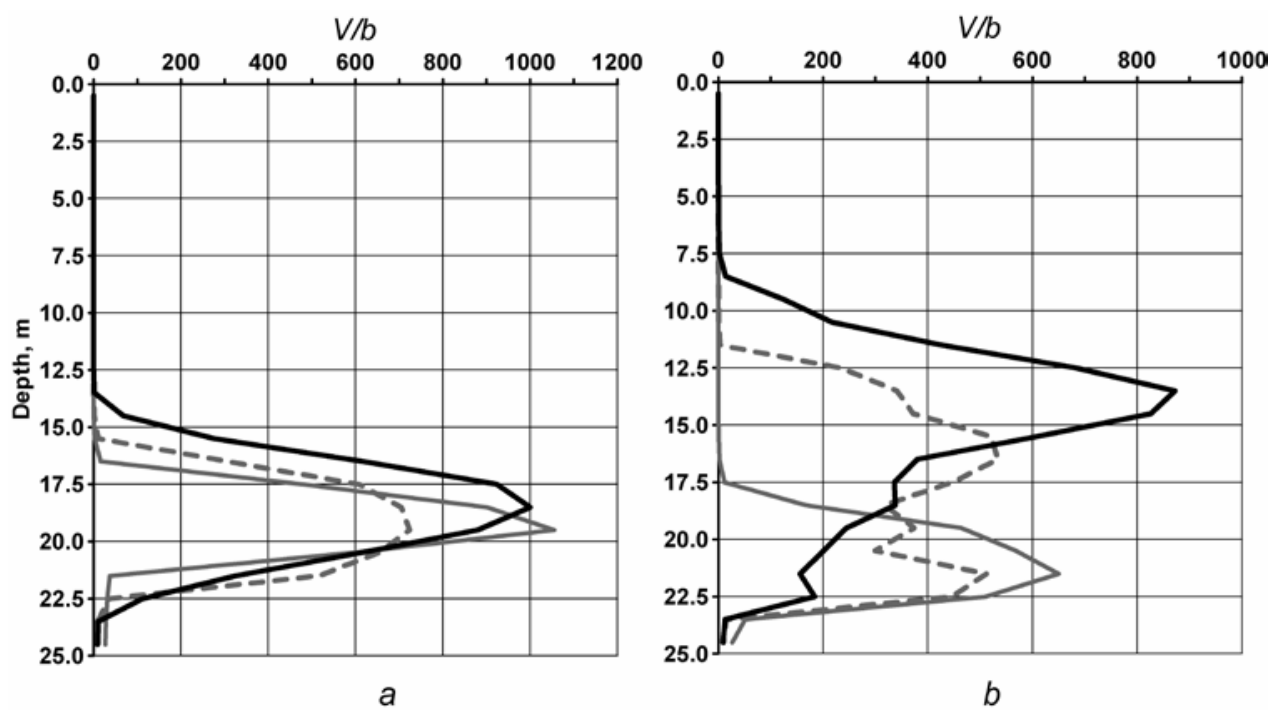

Fig. 4. Distribution of the contaminated zone in the vertical direction where $h_{0}=25 \mathrm{~m}$ for the first $(a)$ and second $(b)$ types of stratification where $t=12 \mathrm{~h}$. Colors and type of curves have the same match as in Fig. 2
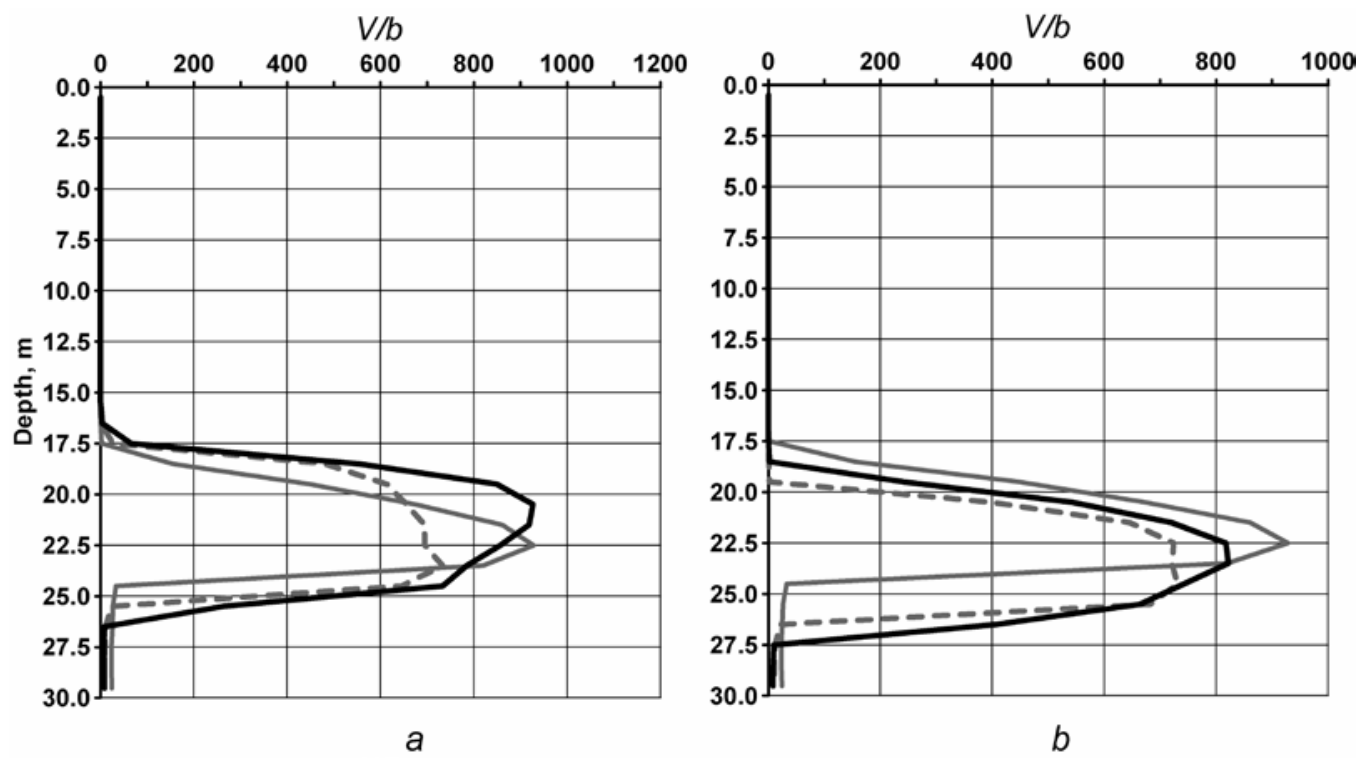

Fig. 5. Distribution of the contaminated zone in the vertical direction where $h_{0}=30 \mathrm{~m}$ for the first $(a)$ and second $(b)$ types of stratification where $t=12 \mathrm{~h}$. Colors and type of curves have the same match as in Fig. 2

PHYSICAL OCEANOGRAPHY NO. 6 (2016) 
Fig. 5 demonstrates the distribution of $V / b$ for $h_{0}=30 \mathrm{~m}$ (the source is located under the density jump for both types of stratification). In this case, the ambient currents have no appreciable effect on the position of the layers of contaminated water. As for the first and second type of stratification, the basic zones of contamination are concentrated in the layer of $\sim 18-27 \mathrm{~m}$.

Tab. 1 shows the maxima values of the areas of contaminated zones $(\max V)$ and their respective horizons $\left(z_{\max }\right)$ for 24 combinations of the problem parameters. Apparently, by varying $U_{0}$ and $h_{0}$, the area of contaminated zones varies from 0.01 to $3.5 \mathrm{~km}^{2}$. The general trend is that when vertical gradients of density and current velocity decrease, contamination area expands. $M a x V$ mean values for the first and second types of stratification are 0.36 and $0.93 \mathrm{~km}^{2}$, respectively. In the second type of stratification the more favorable conditions for the penetration of contaminated water into the sea surface layers (in 6 of 12 cases zones of maximum contamination are located in the upper $2 \mathrm{~m}$ layer) appear.

Density stratification on May 20, 2016. In the second cycle of numerical experiments (Tab. 2), the profiles $T_{0}(z)$ and $S_{0}(z)$ were applied. They are shown in Fig. 1 by solid gray lines (hereinafter - the third type of stratification). These profiles are based on the sensing data over the underwater outlet pipeline at the station with the depth of $\sim 30 \mathrm{~m}$. Such type of profiles, as compared with those described above, is characterized by weak stratification. (Mean value $N$ in $0-30 \mathrm{~m}$ layer is 7.3 cycle/hour). This case is of a particular interest, since it was this station where the $\sim 100-200 \mathrm{~m}$ surface plume of polluted water was visually observed.

Table 2

\section{Maximum Areas of the Contaminated Zones $(\max V)$ and Their Depth $\left(z_{\max }\right)$ and Surface Anomalies $T$ and $S$ for the Third Type of Stratification under Various Values of $U_{0}$}

\begin{tabular}{cccccc}
\hline$h_{0}, \mathrm{~m}$ & $U_{0}, \mathrm{~m} / \mathrm{s}$ & $\max V, \mathrm{~km}^{2}$ & $z_{\max }, \mathrm{m}$ & $\delta T,{ }^{\circ} \mathrm{C}$ & $\delta S, \%$ o \\
\hline 30 & 0.010 & 0.83 & 7.5 & -1.05 & -0.12 \\
30 & 0.025 & 0.85 & 7.5 & -0.78 & -0.08 \\
30 & 0.050 & 0.41 & 8.5 & -0.22 & -0.01 \\
30 & 0.075 & 0.30 & 13.5 & -0.02 & 0.01 \\
\hline
\end{tabular}

Fig. 6 illustrates the third type of stratification the $V / b$ distribution where $h_{0}=$ $=30 \mathrm{~m}$ and three values of $U_{0}$. The curves correspond to the time point $t=12 \mathrm{~h}$. It is shown that when $U_{0}=0.025 \mathrm{~m} / \mathrm{s}$ the layer of $6-10 \mathrm{~m}$ is exposed to the maximal contamination. When $U_{0}$ equals to 0.050 and $0.075 \mathrm{~m} / \mathrm{s}$ the contaminated areas decrease by more than 2 times, as compared with the case when $U_{0}=0.025 \mathrm{~m} / \mathrm{s}$.

It was found that other, less marked layers can appear below the main layer of pollution. Thus, when $U_{0}=0.075 \mathrm{~m} / \mathrm{s}$, the layers of $12-15$ and $20-22 \mathrm{~m}$ turn to be more contaminated. This vertical splitting of the wastewater into several layers is a rather typical phenomenon for the Crimean coastal waters [2]. 


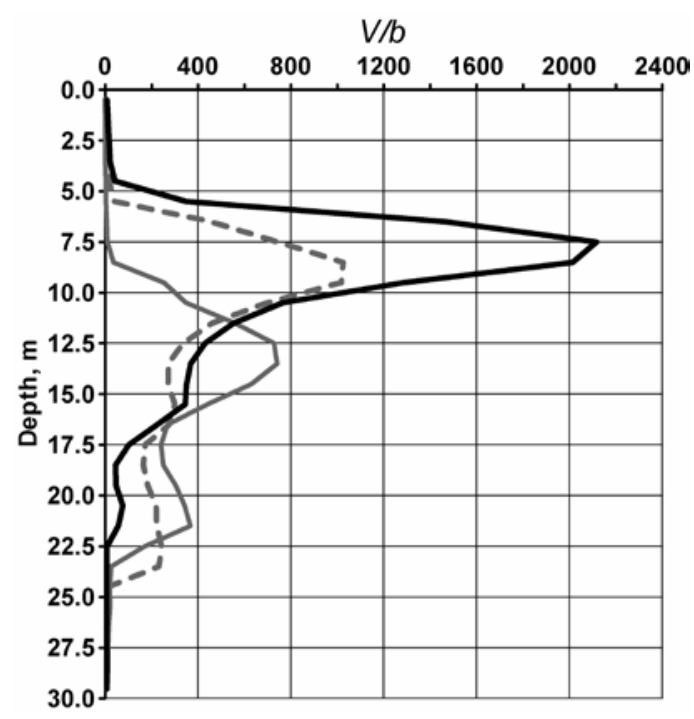

Fig. 6. Distribution of the contaminated zone in the vertical direction where $h_{0}=30 \mathrm{~m}$ for the third type of stratification where $t=12 \mathrm{~h}$. Colors and type of curves have the same match as in Fig. 2

According to Tab. 2, the areas of contamination zones of the third type of stratification are $\sim 0.6 \mathrm{~km}^{2}$ on average with the mean location depth of $\sim 9.3 \mathrm{~m}$.

Vertical structure of the contaminated water field for the third type of stratification is demonstrated in Fig. 7. Here one can see the function isolines where $t=12 \mathrm{~h}$ for three values of $U_{0}$. The dimensionless magnitude $x / d$ is plotted along the horizontal coordinate. Peculiarities of the considered fields are the stem rising from the underwater outlet and the jet oriented along the direction of the ambient current. With the current velocity increase, the stem top is lowered and the jet is elongated in the longitudinal direction and is vertically compressed by penetration at the upper boundary of $\sim 5 \mathrm{~m}$.

The simulation results showed that, according to the criterion $c \geq 5 \%$, the jet cross-scale at $1 \mathrm{~km}$ distance of 1 from the source can reach $\sim 500 \mathrm{~m}$ where $U_{0}=$ $=0.025 \mathrm{~m} / \mathrm{s}$ and $250-200 \mathrm{~m}$ at the other two values of $U_{0}$. Appearance of the contaminated water jet on the six characteristic horizons where $U_{0}=0.050 \mathrm{~m} / \mathrm{s}$ is shown in Fig. 8. The jet is clearly seen in $7.5-9.5 \mathrm{~m}$ layer, it has a transverse dimension of $\sim 200 \mathrm{~m}$. Outside this layer the jet sharply narrows up to $50 \mathrm{~m}$ or less.

Identification of underwater jets is usually made on the basis of a series of vertical probings perpendicular to the direction of the jet propagation [2]. With small transverse dimensions such method does not exclude skipping of the axial section of the jet, which probably happened on May, 20, 2016 in the measurement of water turbidity in the area of the underwater outlet.

Next evaluate the magnitudes of surface temperature and salinity anomalies using the following relations:

$$
\delta T=\overline{T\left(x_{\mathrm{p}}, y_{\mathrm{p}}, 0, t\right)}-T_{0}(0), \quad \delta S=\overline{S\left(x_{\mathrm{p}}, y_{\mathrm{p}}, 0, t\right)}-S_{0}(0),
$$

where the overbar denotes averaging over a period of $12 \mathrm{~h}$. 

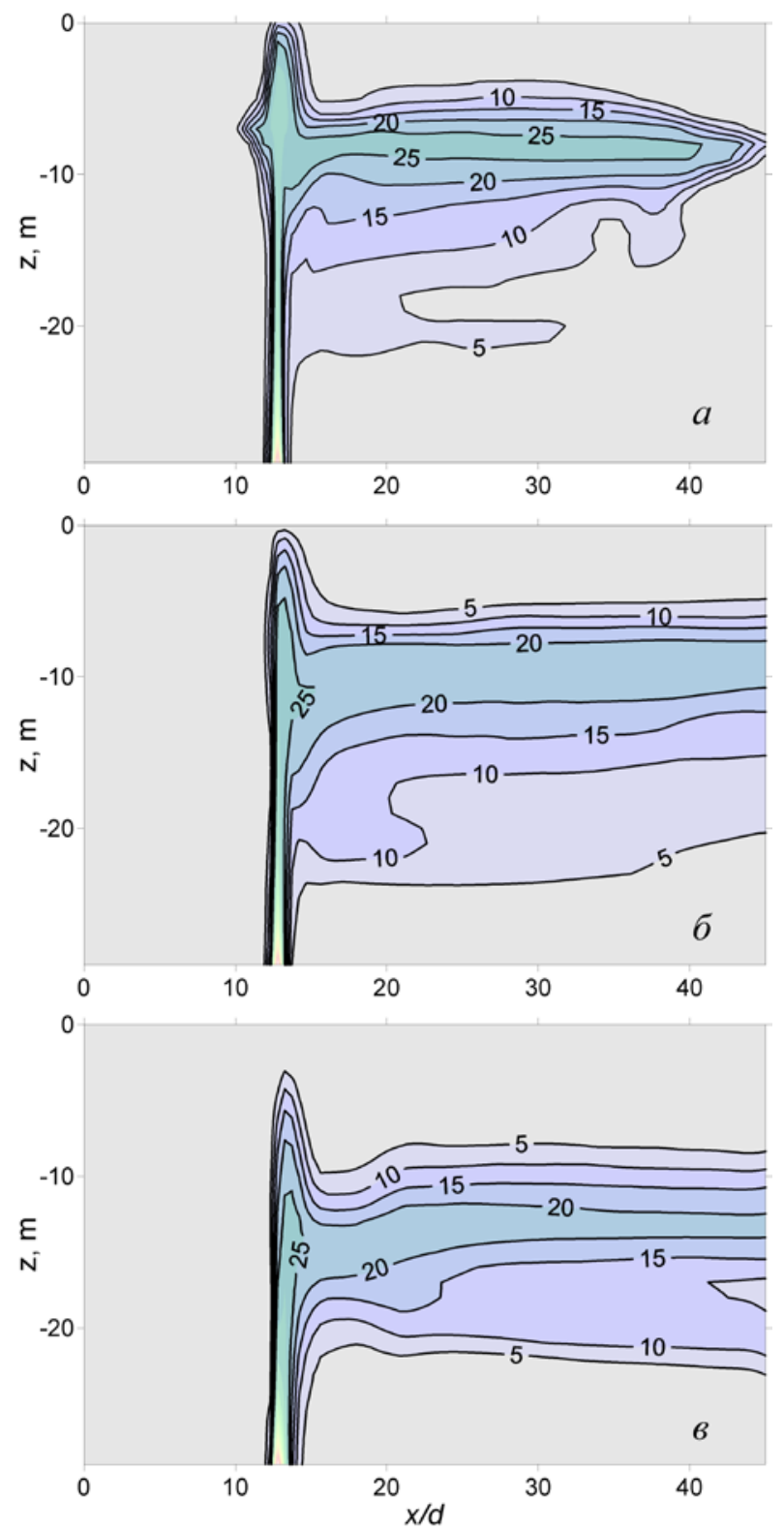

Fig. 7. Isolines of the function $c\left(x, y_{\mathrm{p}}, z, t=12 \mathrm{~h}\right)$ for the third type of stratification: $a$ - where $U_{0}=$ $=0.025 \mathrm{~m} / \mathrm{s} ; b-$ where $U_{0}=0,050 \mathrm{~m} / \mathrm{s} ; \boldsymbol{\beta}$ - where $U_{0}=0,075 \mathrm{~m} / \mathrm{s}$

Calculations by the formulas (16) show that there are negative temperature and salinity anomalies generated right above the wastewater source (Tab. 2). Their values depend on the velocity of ambient currents. When $U_{0}=0.025 \mathrm{~m} / \mathrm{s}$ the value of the temperature anomalies reaches $-1^{\circ} \mathrm{C}$, that of salinity anomalies $-0,1 \%$. 

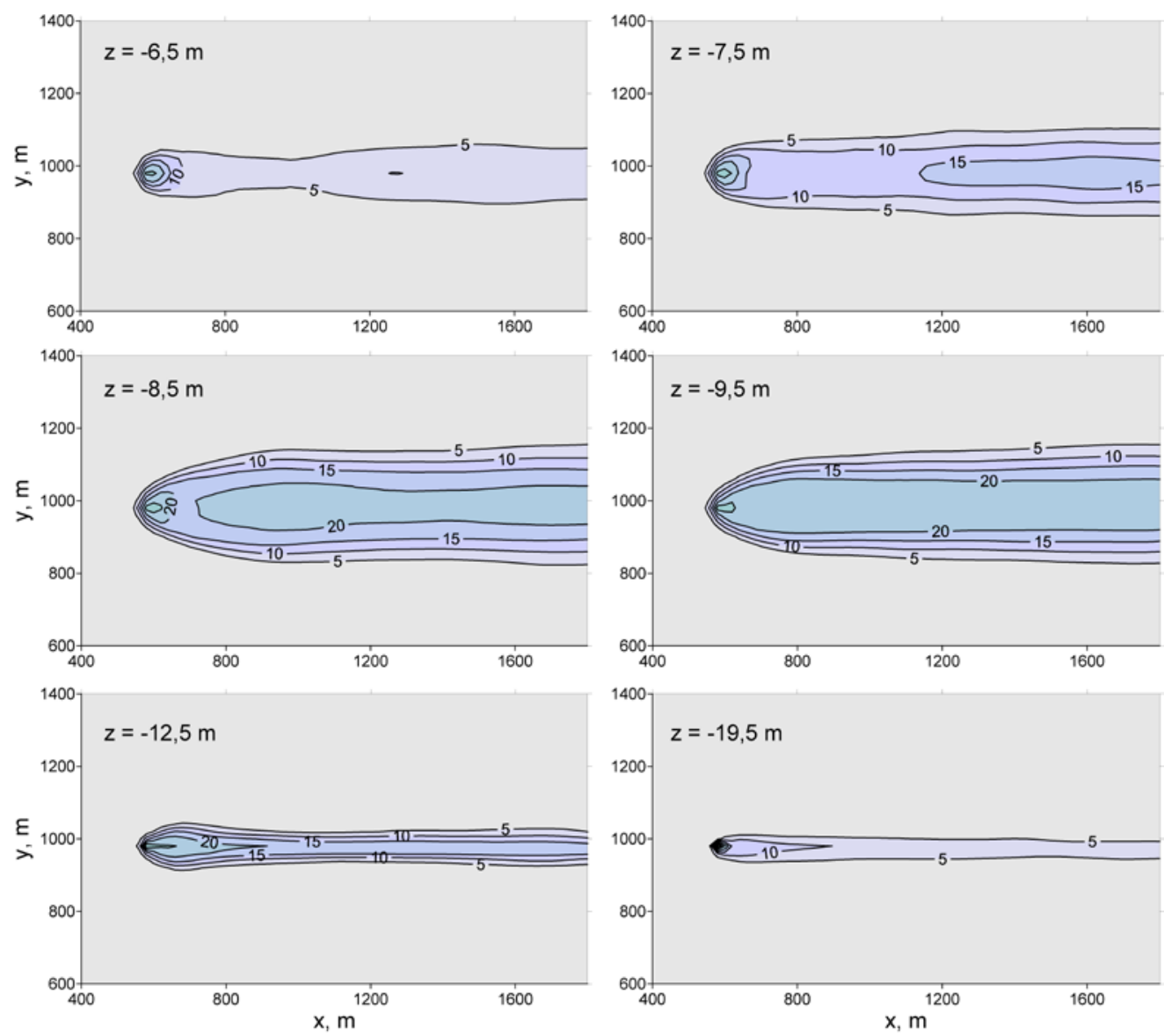

Fig. 8. Isolines of the function $c\left(x, y, z_{k+1 / 2}, t=12 \mathrm{~h}\right)$ for the third type of stratification where $U_{0}=$ $=0,050 \mathrm{~m} / \mathrm{s}$ and at various values of $k$

Conclusion. The article concerns the problem of wastewater propagation over the Heraklean Peninsula coastal zone from the underwater source simulating a break on the Sevastopol major municipal sewage pipeline.

On the basis of the three-dimensional numerical model the calculations of initial stages of wastewater propagation for three types of density stratification obtained by R/V Biryuza in September, 2015 and May, 2016, were carried out. The water discharge in the source was $1.4 \mathrm{~m}^{3} / \mathrm{s}$. The effect of positive buoyancy in the model was created by fresh water inflow. The outlet depth $h_{0}$ ranged from $15-$ $30 \mathrm{~m}$, the ambient current velocity $U_{0}$ was in the range of $0.025-0.075 \mathrm{~m} / \mathrm{s}$.

Analysis of the simulation results showed that the outlet of contaminated water to the surface depends on both the characteristics of density stratification and on $U_{0}$ and $h_{0}$ values. The main factor impeding the contaminated water rise is the presence of layers with density jumps above the source.

The general trend is that when vertical gradients of density and current velocity decrease, contamination area expands. The area of contaminated water areas varies between $0.4-0.9 \mathrm{~km}^{2}$. 
Wastewater field near the source consists of the stem rising from an underwater outlet and the jet oriented along the direction of the ambient current. As $U_{0}$ increases, the top of the stem lowers and the jet sinks, its transverse size simultaneously decreases. In some cases the wastewater field splits vertically into two layers.

On the water surface above the source the negative anomalies of temperature and salinity are formed. They reach $-1{ }^{\circ} \mathrm{C}$ and $-0.1 \%$, respectively.

The results can be used for interpretation and planning of field experiments on the wastewater propagation in the area of the Crimean Peninsula.

Acknowledgements. The research was carried out under the sponsorship of the Ministry of Education and Sciences of the Russian Federation within the framework of the Federal Target Program "Research and Development in Priority Development Directions of the scientific-technological complex in the Russian Federation 2014 - 2020" (unique project code RFMEFI57714X0110).

\section{REFERENCES}

1. Bondur, V.G., Grebenyuk, Yu.V., 2001, "Distantsionnaya indikatsiya antropogennykh vozdeystviy na morskuyu sredu, vyzvannykh zaglublennymi stokami: modelirovanie, eksperimenty [Remote indication of anthropogenic impacts on the marine environment caused by underwater runoffs: modeling and experiments]", Issledovanie Zemli iz kosmosa, no. 6, pp. 49-67 (in Russian).

2. Gol'dberg, G.A., Zaets, V.I. \&. Atsikhovskaya, Zh.M. [et al.], 1991, “Modelirovanie protsessov samoochishcheniya vod shel'fovoy zony morya [Modeling of self-purification processes of the shelf sea waters]”, Leningrad, Gidrometeoizdat, 230 p. (in Russian).

3. Bondur,V., 2005,“Complex satellite monitoring of coastal water areas”, 31st International Symposium on Remote Sensing of Environment, June 20-24, 2005, Saint Petersburg, 7 p.

4. Valery G. Bondur, 2011, "Satellite Monitoring and Mathematical Modelling of Deep Runoff Turbulent Jets in Coastal Water Areas, Waste Water - Evaluation and Management”, InTech, DOI: 10.5772/16134, http://www.intechopen.com/books/waste-water-evaluation-andmanagement/satellite-monitoring-and-mathematical-modelling-of-deep-runoff-turbulent-jetsin-coastal-water-areas

5. Keeler, R., Bondur, V. \& Vithanage, D., Apr. 2004, "Sea truth measurements for remote sensing of littoral water”, Sea Technol., pp. 53-58.

6. Bondur, V.G., Filatov, N.N. \& Grebenyuk, Yu.V. [et al.], 2007, “Issledovaniya gidrofizicheskikh protsessov pri monitoringe antropogennykh vozdeystviy na pribrezhnye akvatorii (na primere bukhty Mamala, o. Oakhu, Gavayi) [Research of hydrophysical processes in monitoring of anthropogenic impact on coastal waters (on the example of Mamala Bay of Oahu, Hawaii)]”, Okeanologiya, vol. 47, no. 6. pp. 827-846 (in Russian).

7. Blumberg, A., Ji, Z. \& Ziegler, C., 1996, "Modeling outfall plume behavior using far field circulation model”, J. Hydraul. Engineer., vol. 122, no. 11, pp. 610-616.

8. Zhang, X., Adams, E., 1999, "Prediction of near field plume characteristics using far field circulation model”, J. Hydraul. Engineer., vol. 125, no. 3, pp. 233-241.

9. Bondur, V.G., Zhurbas, V.M. \& Grebenyuk, Yu.V., 2006, “Matematicheskoe modelirovanie turbulentnykh struy glubinnykh stokov v pribrezhnye akvatorii [Mathematival modeling of the underwater runoff turbulent jets in the coastal waters]”, Okeanologiya, vol. 46, no. 6, pp. 805820 (in Russian). 
10. Bondur, V.G., Grebenyuk, Yu.V. \& Ezhova, E.V. [et al.], 2010, "Poverkhnostnye proyavleniya vnutrennikh voln, izluchaemykh zaglublennoy plavuchey struey. Ch. 3. Poverkhnostnye proyavleniya vnutrennikh voln [Surface manifestations of internal waves emitted by the underwater floating jet. Part 3. Surface manifestations of internal waves]”, Izv. RAN. Fizika atmosfery i okeana, vol. 46, no 4, pp. 519-529 (in Russian).

11. Sovga, E.E., Pasynkov, A.A. \& Andreeva, O.A., 2011, "Ekologicheskoe sostoyanie pribrezhno-morskikh rayonov Kryma [Ecological state of coastal-marine areas of Crimea]", Ekologicheskaya bezopasnost' pribrezhnoy i shel'fovoy zon i kompleksnoe ispol'zovanie resursov shel'fa, iss. 25, pp. 169-180 (in Russian).

12. Ivanov, V.A., Fomin, V.V., 2008, "Matematicheskoe modelirovanie dinamicheskikh protsessov $v$ zone more - susha [Mathematical modeling of dynamic processes in sea-land area]”, Sevastopol, ECOSI-Gidrofizika, 363 p. (in Russian).

13. Fomin, V.V., Polozok, A.A. \& Fomina, I.N, 2015, "Simulation of the Azov Sea Water Circulation Subject to the River Discharge”, Physical Oceanography, no. 1, pp. 15-26.

14. Mikhailova, E.N., Shapiro, N.B., 2014, "Trekhmernaya negidrostaticheskaya model' submarinnoy razgruzki v pribrezhnoy zone morya [Three-dimensional non-hydrostatic model of underwater discharge in the coastal zone]”, Morskoy gidrofizicheskiy zhurnal, no. 4, pp. 28-50 (in Russian).

15. Smagorinsky, J., 1963, "General circulation experiments with primitive equations, I. The basic experiment”, Mon. Wea. Rev., vol. 91, no. 3, pp. 99-164.

16. Mellor, G.L., Yamada, T., 1982, "Development of a turbulence closure model for geophysical fluid problems”, Rev. Geophys. Space Phys., vol. 20, no. 4, pp. 851-875.

17. Fomin, V.V., 2006, "Primenenie TVD-skhem dlya chislennogo modelirovaniya frontal'nykh zon solenosti $v$ melkom more [The use of TVD-schemes for numerical modeling of the frontal zones of salinity in the shallow sea]", Meteorologiya i gidrologiya, no. 2, pp. 59-68 (in Russian).

18. Harten, A. 1984, "On a class of high resolution total-variation-stable finite-difference schemes”, Society for Industrial and Applied Mathematics, vol. 21, no. 1, pp. 1-23.

19. Morozov, A.N., Ivanov, V.A. \& Shutov, S.A. [et al.], 2016, "Prostranstvennaya struktura techeniy u Gerakleyskogo poluostrova po dannym ADCP nablyudeniy 2015 g. [Currents' space structure near Heracles Peninsula according to ADCP observational data, 2015]”, Ekologicheskaya bezopasnost' pribrezhnoy i shel'fovoy zon morya, , iss. 1, pp. 73-79 (in Russian). 